\title{
The linguistic synonymy phenomenon of Coptic words and their Greek equivalent through the published Coptic documents
}

\section{The linguistic synonymy phenomenon of Coptic words and their Greek equivalent through the published Coptic documents}

\author{
Walaa Ali Abd El-rhman \\ Faculty of Archeology, Cairo University \\ drwalaaali32@yahoo.com
}

\begin{abstract}
The present research addresses a study one of the common linguistic phenomena in Coptic documents, which is represented in using linguistic synonyms between Coptic words and their Greek equivalents to express the same meaning.

The research follows the linguistic analysis methodology for each synonym in terms of defining the meaning, classifying it grammatically and its linguistic derivation depending on the specialized Coptic and Greek dictionaries, then focus on these synonyms in published Coptic documents and then giving examples of them, and these synonyms will be divided into sets according to their types and uses, taking into account the alphabetical order in their study.

The research aims primarily to conduct a comparative analytical study of these synonyms through the documents to determining the types of these synonyms and clarifying the subtle semantic differences between them.

finding the reasons for the prevalence of this phenomenon, trying to find out some writing styles which common among the Copts, in addition to trying dating this phenomenon. Finally, the research hopes to be a nucleus for preparing a dictionary for the Coptic language that presents the material of its words according to the Coptic synonyms and their Greek equivalents.
\end{abstract}

Keywords: Coptic, Greek, Linguistic phenomenon, Synonyms, verbs, nouns, expressions.

\section{Introduction}

Synonymy in general is a type of semantic relationship among words that can be applied to two or more words that share one meaning, what is interesting is that the Coptic language borrowed words from the Greek language, although it has their equivalents. This negates what is commonly known that the Copts' use of Greek vocabulary in their documents came to fill the deficit of some linguistic connotations that cannot be expressed in their language, which raises the question of why the Copts borrowed these synonyms? Hence the importance of this research, whose study is based on finding the reasons for using these Greek synonyms in Coptic documents. This study is divided into two main parts: complete synonym, partial synonym, and several other divisions fall under them according to the nature of these synonyms. 


\section{JOURNAL OF THE FACULTY OF ARCHAEOLOGY -VOLUME 25 -2022}

\section{Complete Synonyms}

It is a kind of Coptic and Greek synonyms that are completely identical in meaning, which can be divided into several types according to the user of both synonyms as follows:

\section{1) Educational Synonyms}

In this group, the Greek synonyms came one time only in Coptic documents, which is evident from studying the documents that they are either list as a type of teaching Greek language or that they are part of the Greek words dictionary which consists for the most of Greek words with their Coptic and Arabic equivalents. where the Copts made lists of the names of different things and topics to facilitate the writing process when a person needed a word that he was missing while writing a letter, a document, or something else, he would search in one of these lists contain words for the Coptic and Greek languages used in daily dealings by the Copts, and sometimes there is a synonym for the word in Arabic.

- aq noun means "fly", Egy. from "tff" (Westendorf, 1977), EX: aq reßsw, the Greek

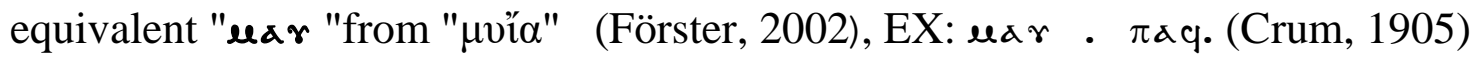

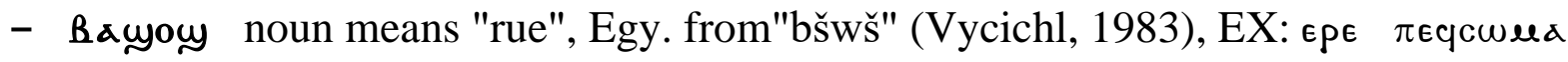

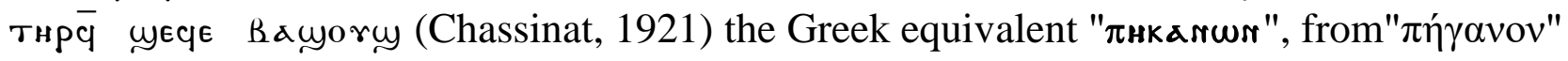

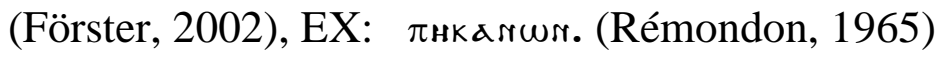

- елтреге expression means "freedom" (Crum, 1939), Egy. from "mdt rmt-nmh" (Černy, 1976), consist of ( $\mu$ sт:prefix forming abstract nouns, рuгн: noun means "free

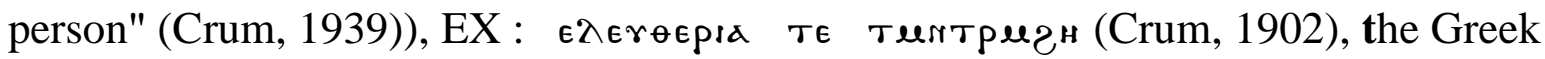

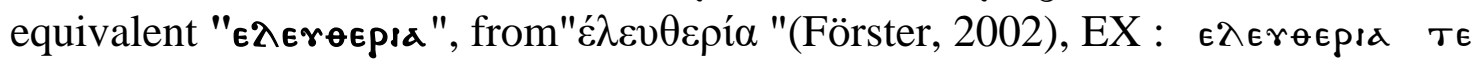
тегтрегн. (Crum, 1902)

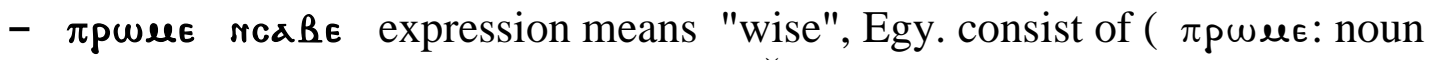
means"man " (Crum, 1939), from "rmt "(Černy, 1976), caß€: adjective means "wise"

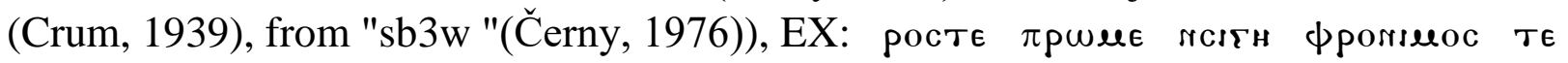

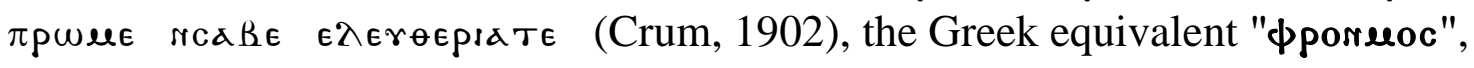

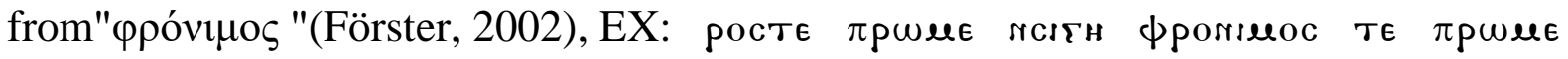

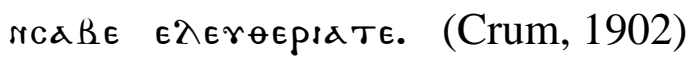

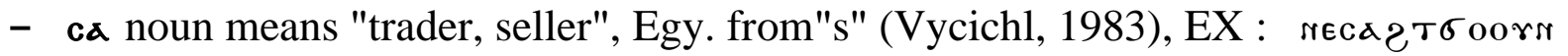

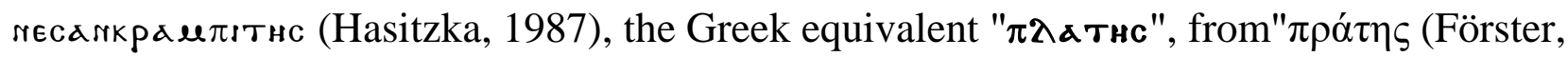

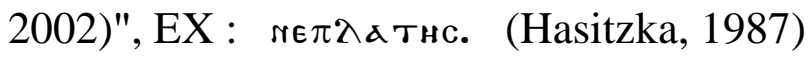

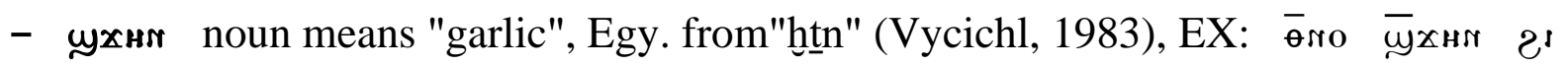

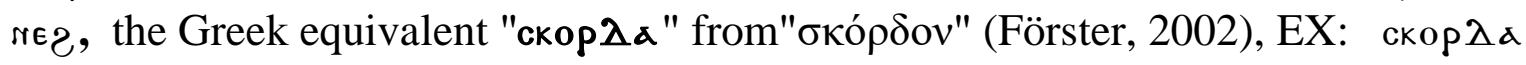
uухнr. (Rémondon, 1965)

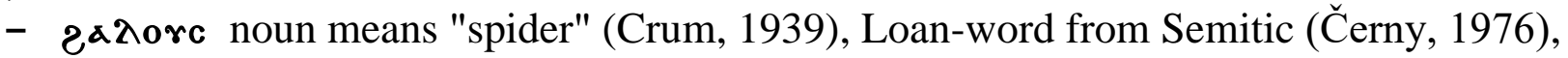

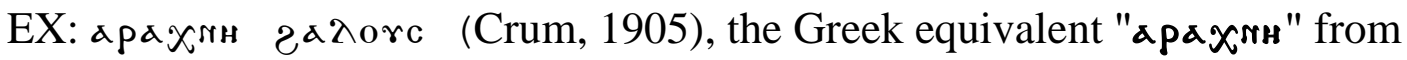

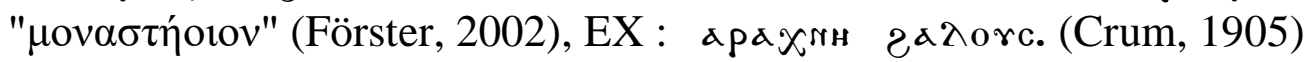




\section{The linguistic synonymy phenomenon of Coptic words and their Greek equivalent through the published Coptic documents}

\section{2) Synonyms for preventing repetition and emphasize the meaning}

This set includes numbers of Coptic and Greek synonyms that exactly match whether in their meaning and use, but it was noticed through the study of documents that the use of the Coptic synonym is the basis for expressing the intended meaning, and when the writer wants to confirm or repeat the meaning in the same document, he often used the Greek equivalent for it.

- ацадтє verb means "prevail" (Crum, 1939), Egy. from "imḥti" (Černy, 1976), Ex:

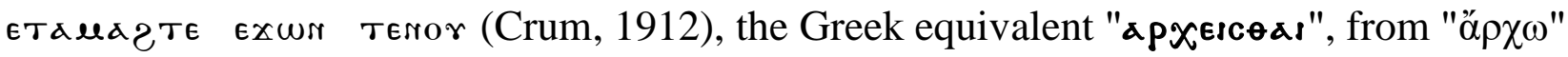

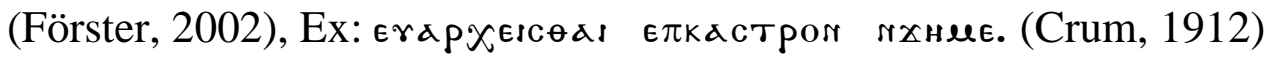

- нрл noun means "wine", Egy. from"irp "(Vycichl, 1983), EX: + тs чуолте $\overline{\mu ф ф о р н с ~ к н р ~} \bar{\pi}$ (Crum, 1922), the Greek equivalent "osrr", from"oĩvo $"$ " (Förster, 2002), it was mostly used only when the writer wants to repeat the same amount of wine again (Walaa, 2021), for example in working documents when the wine is part of the wage, EX: os, $k r \lambda \mathrm{k} \lambda \mathrm{crs}$ тprsтs,. (Till, 1956), it is noted that the abbreviated form was followed as a method in writing this word.

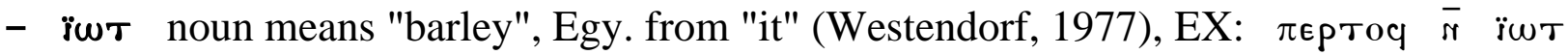

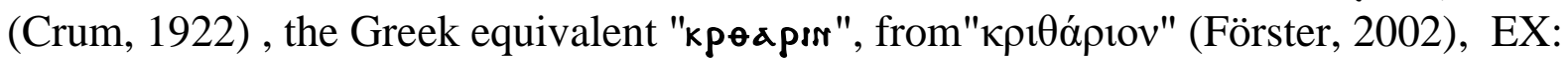

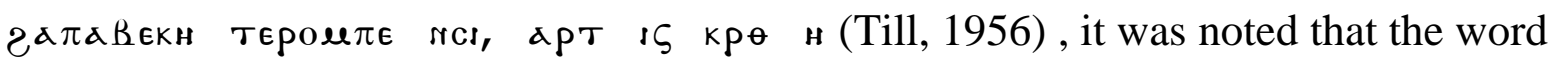
кpedpor is always used in its abbreviated form except one document, which is a list of a group of Greek words with their Coptic equivalent. (Rémondon, 1965)

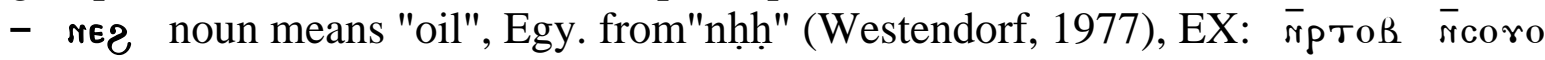

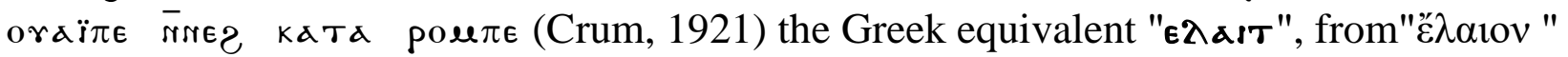

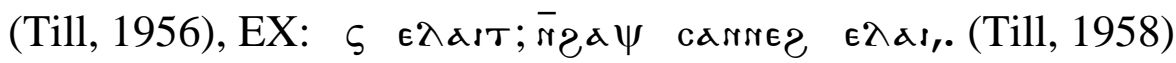

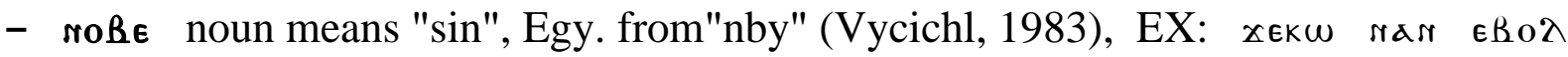

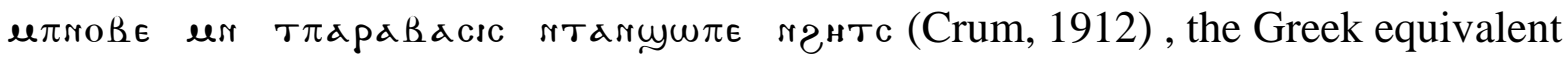

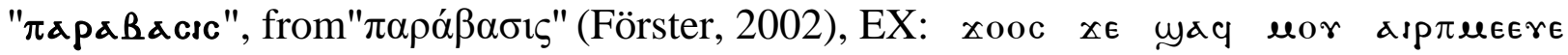

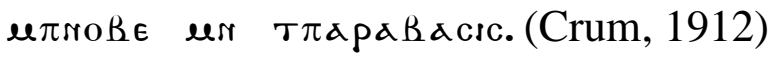

- $\quad$ co $\pi \mathrm{c} \epsilon \pi$ verb means "pray - intercede " (Crum, 1939), Egy. from"spr" (Černy, 1976),

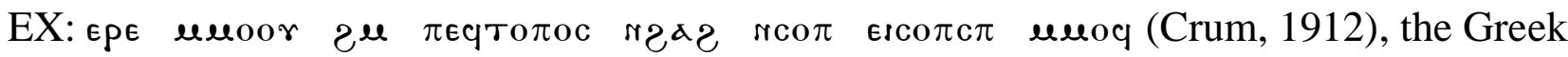

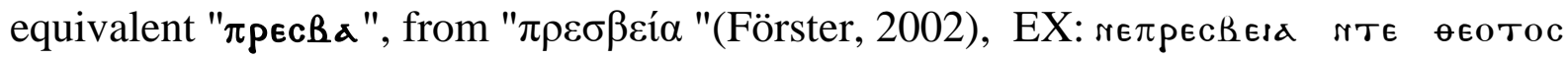

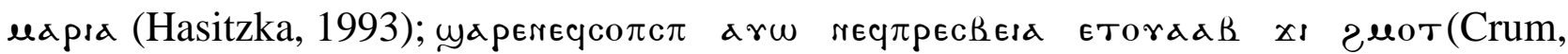
1912), Both synonyms were restricted to the use of blessed formulas.

- coro noun means "wheat" (Crum, 1939), Egy. from"swt "(Černy, 1976), EX: rcoor мртоя rсого (Crum, 1905), the Greek equivalent "crтoc", from "бĩ EX: za $a$ a

The Greek word crтoc is used often when the writer wants to repeat the same amount of wheat, especially in working documents when the wheat is part of the wage. 
- Taxpo noun means "power" (Crum, 1939), Egy. from"ty dr "(Černy, 1976), EX:

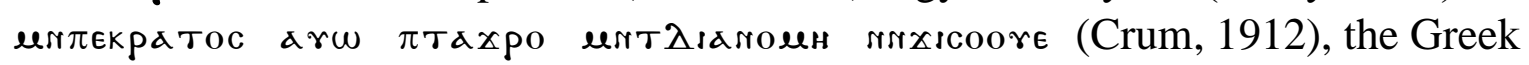

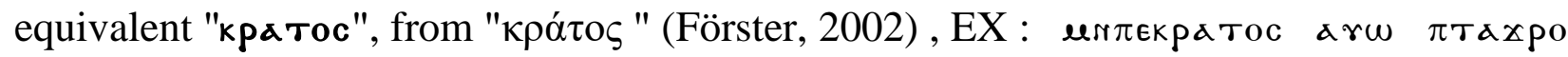
ентлгляоен . (Crum, 1912)

- wrr noun means "life", Egy. from "nh" (Westendorf, 1977), EX : xєormse

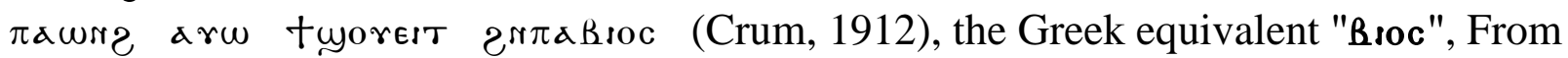

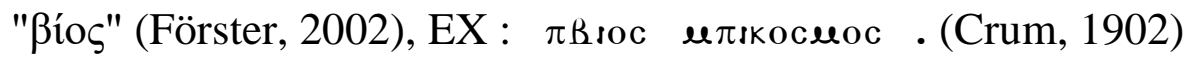

- yудєлє尺 expression means "eternal", Egy. consist of ( ya: preposition means "toward " (Crum, 1939), from "r-š3 c" (Černy, 1976), єrє२: noun means "eternity" (Crum, 1939),

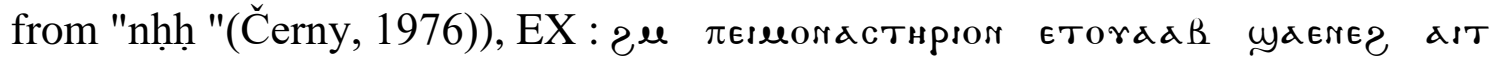

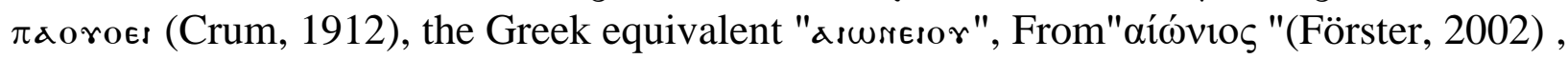
EX : zikatoxн rasumsor . (Crum, 1912)

- yysre verb means "greet", Egy. from"šny" (Černy, 1976), EX: esc̨ä̈ esursse

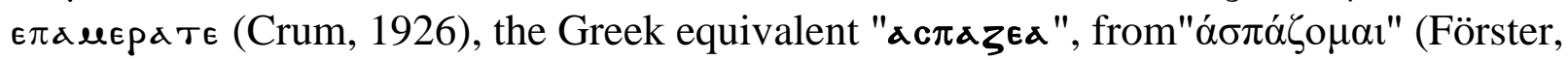

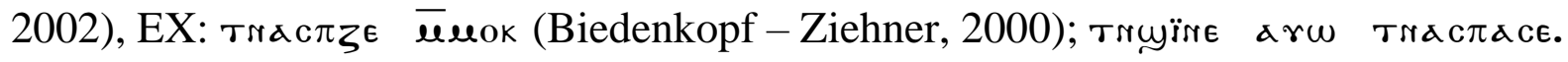
(Crum, 1926)

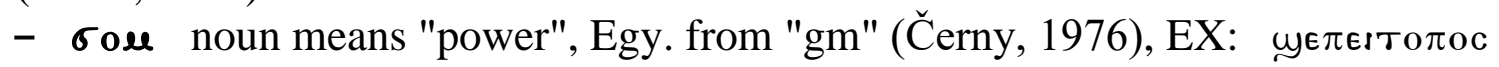

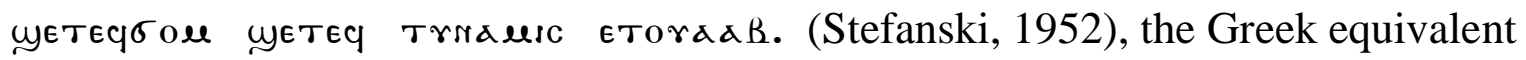

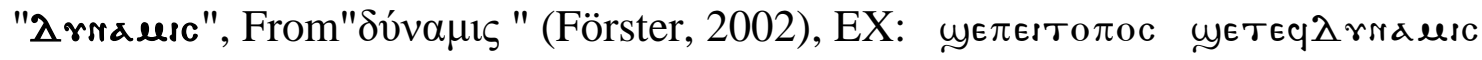
EтoradR. (Stefanski, 1952)

\section{3) Synonyms as a kind of polyphony of one meaning used according to the preferences of writer}

This set includes numbers of Coptic and Greek synonyms were well known to the Copts and both words were common in documents, which are absolutely interchangeable in any contexts thus capable of being used to substitute one another without any noticeable difference in their meanings or uses, therefore both were used according to the writer's preferences, and each words were appeared in different documents as a kind of multiple expression of one meaning, an addition to this considered one of the writing methods used by the Copts.

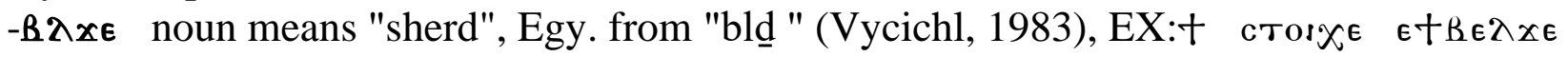

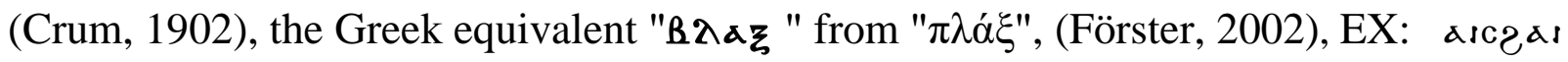
$\pi \in ı \pi \lambda_{\alpha}$. (Leipoldt, 1904)

- Өro verb means "hire", Egy. from"dit hn" (Černy, 1976), Ex: akөros єтрарұwB (Crum,

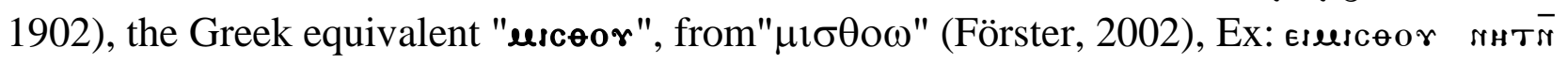
уоите мроите. (Till, 1958)

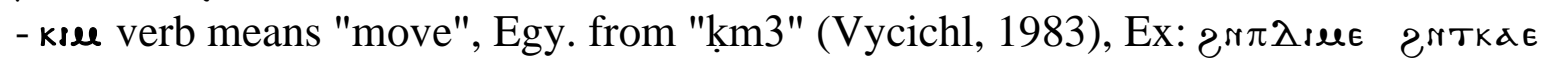

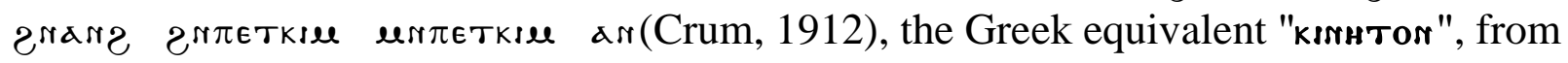

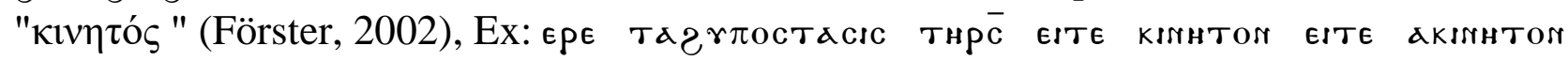

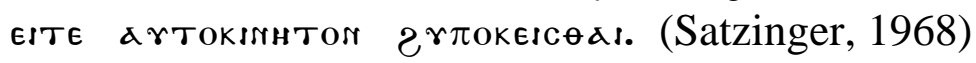




\section{The linguistic synonymy phenomenon of Coptic words and their Greek equivalent through the published Coptic documents}

- щusrorte expression means "loving god", Egy. consist of ( exs: prefix means "loving", from "mr" (Černy, 1976)used with nouns to forming adjective (Crum, 1939), погтє: noun

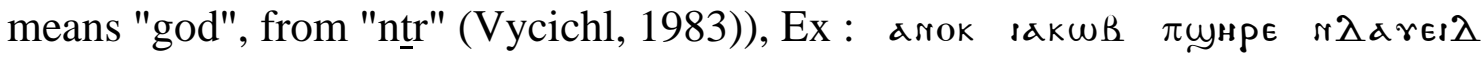

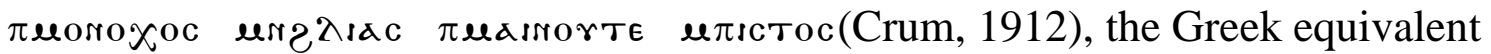

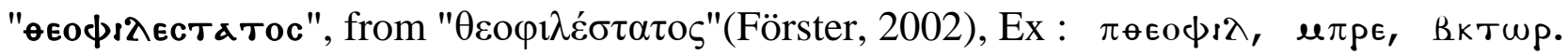
(Crum, 1902)

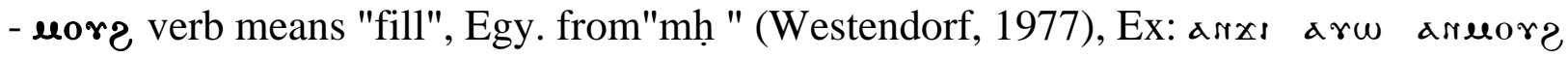

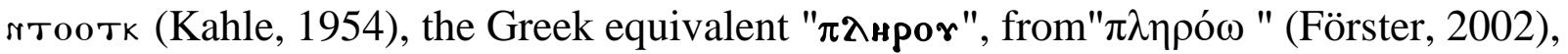

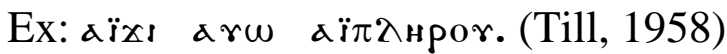

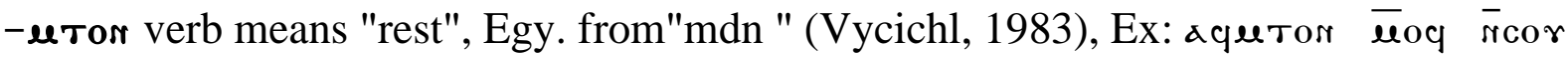
(Hasitzka, 1993), the Greek equivalent "asa Eraratarcic rrererote etorad. (Crum, 1912)

The Coptic verb uтor is used especially in Coptic stelae.

- na noun means "mercy" (Crum, 1939), Egy. from "nc" (Černy, 1976), EX: a pıлma

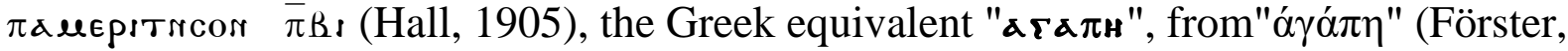

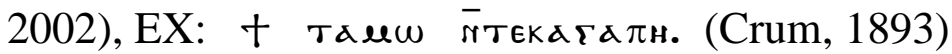

- oce noun means "fine" (Crum, 1939), Egy. from"isy" (Černy, 1976), EX: asror

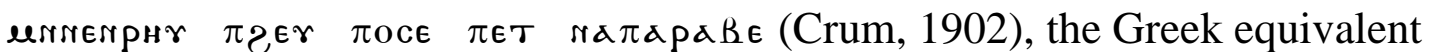

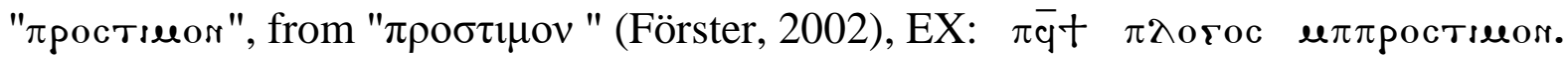
(Schiller, 1931)

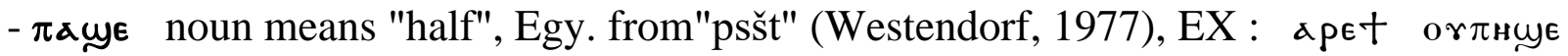

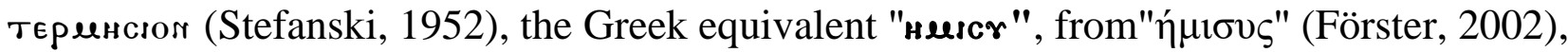
EX : xprcō rouscesta нuscr. (Till, 1960)

- pєq†२ $\pi \pi$ means "judge" (Vycichl, 1983), Egy. consist of ( pєq: prefix forming agent of verbs, from "rmt iw.f " (Černy, 1976), †: verb means "give", from "rdi" (Westendorf,

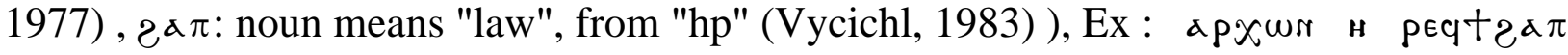

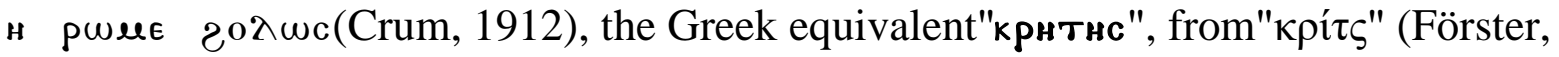

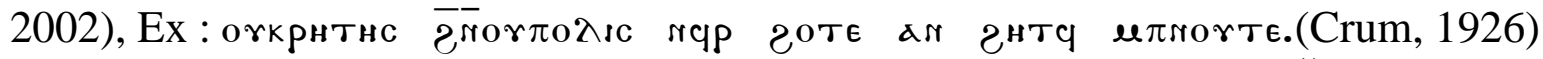
- poesc verb means "watch- be awake"(Crum, 1939), Egy. from "ris" (Černy, 1976), Ex:

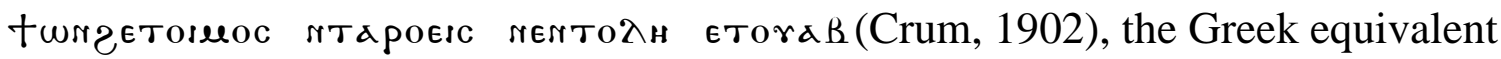

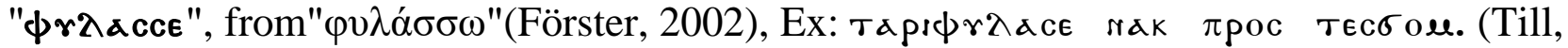
1958)

- coorrs verb means "know", Egy. from"swn" (Černy, 1976), Ex: ascəas zapoor

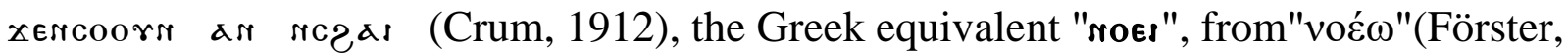

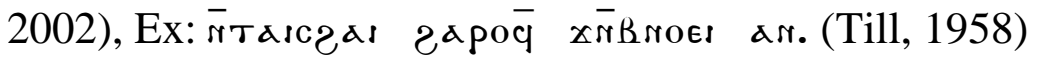

- тнr noun means "wind" (Crum, 1939), Egy. from "ț3w " (Černy, 1976), EX: пток

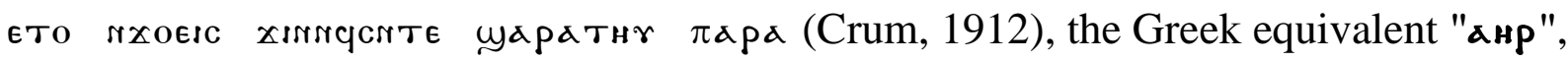

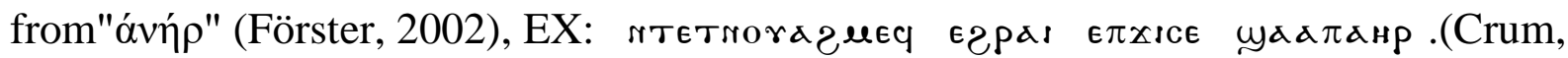
1912) 
- тoor noun means "mountain", Egy. from "dw " (Vycichl, 1983), EX: a $\pi$ a porkarewr

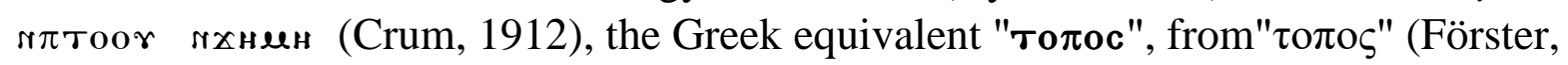

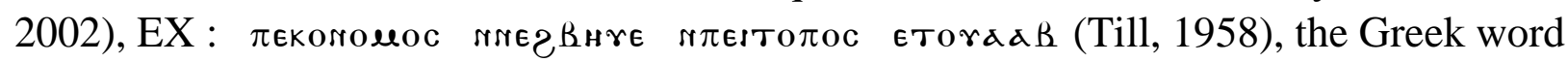
толос includes multiple meanings in Coptic documents, while the Coptic word has one meaning.

- yyбop noun means "rent" (Crum, 1939), Egy. from"škr " (Černy, 1976), EX: єлєry్ op

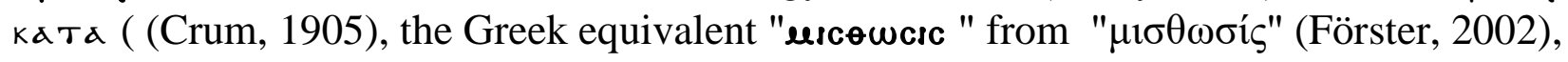

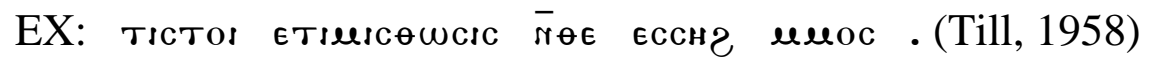

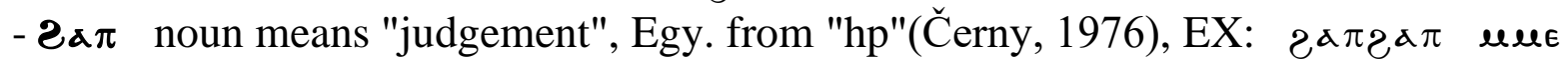

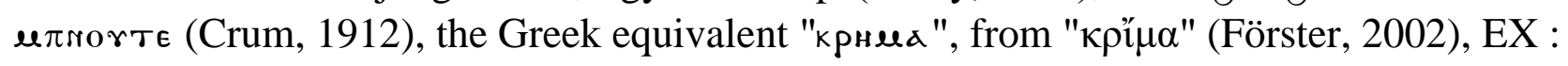

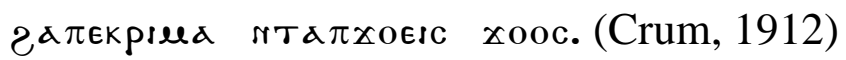

- Zетєете noun means "monastery " (Crum, 1939), Egy. from"ḥ(w).t nțr "(Vycichl, 1983),

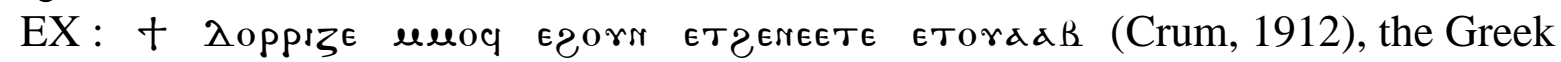

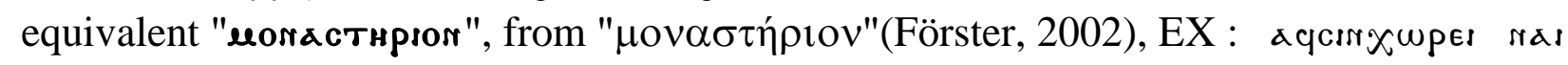
єВок є२огя єлеоластнртол. (Crum, 1912)

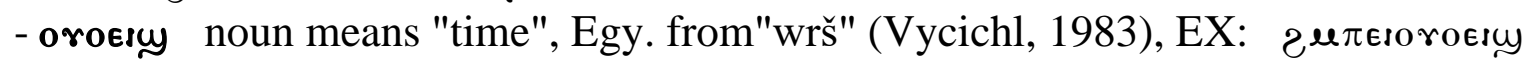
єтеsear (Crum, 1912), the Greek equivalent "kaspoc"(Crum, 1939), from "кaıрóc"

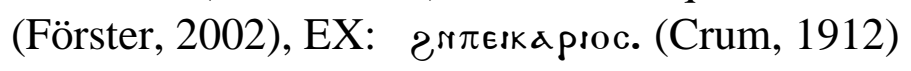

\section{4) Synonyms are used to show the culture of the writer}

This group is distinguished by the fact that the use of Greek synonyms was in a few documents, and there was no explanation for their use other than the desire of the document writer to show his culture and knowledge of the Greek language, therefore it can be said that the Greek synonym in this group was not familiar to the Copts, and the basis for expression the intended meaning is the use of the Coptic synonym.

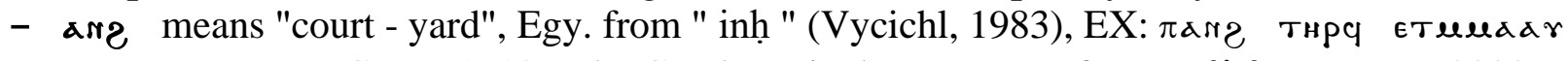

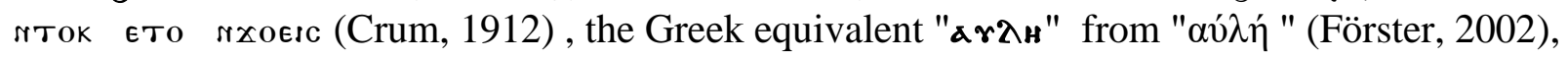

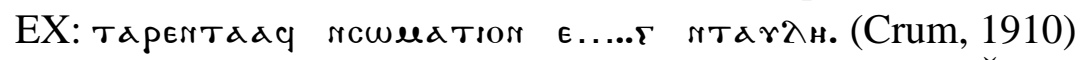

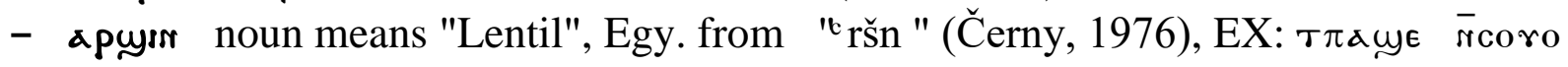

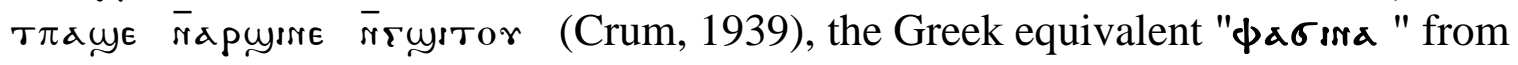

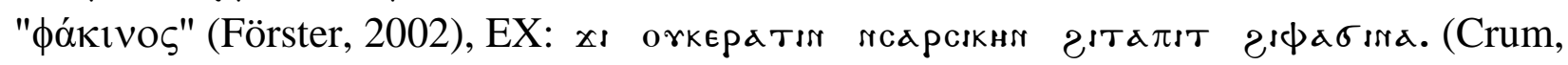
1909)

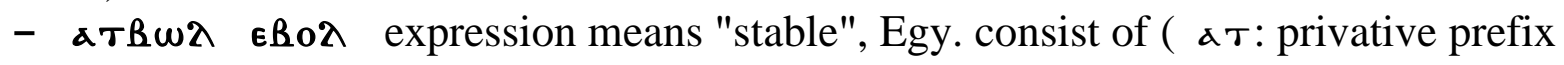
means "without ", from "iw.t-y " (Vycichl, 1983) used with verbs to forming negation

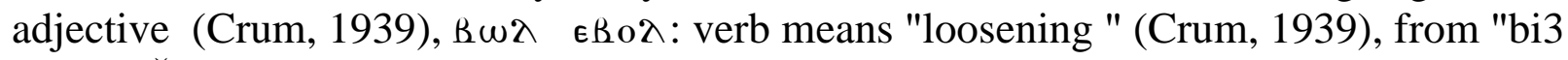

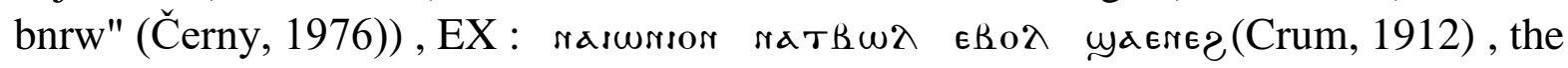

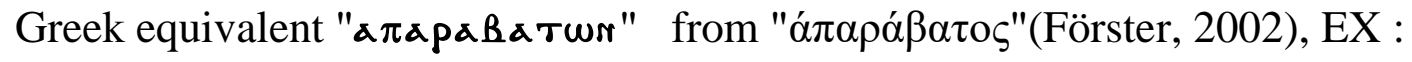

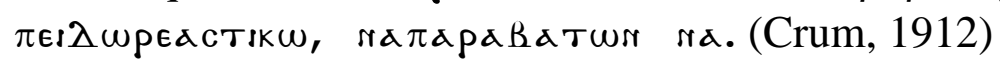




\section{The linguistic synonymy phenomenon of Coptic words and their Greek equivalent through the published Coptic documents}

- $\epsilon \ddot{i}$ verb means "come " (Westendorf, 1977), Egy. from "iy "(Černy, 1976), Ex: eкuyareï елгет

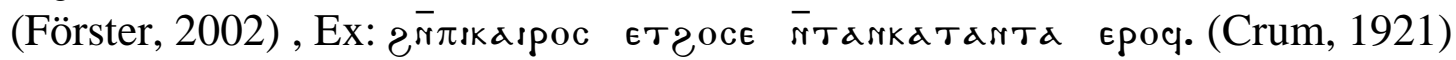

- атунре expression means "sterile "Egy. consist of ( а т: privative prefix means "without ", from "iw.t-y" (Vycichl, 1983) used with nouns to forming negation adjective (Crum, 1939), уунрє: noun means "son" (Crum, 1939), from "šri"(Černy, 1976)), EX :

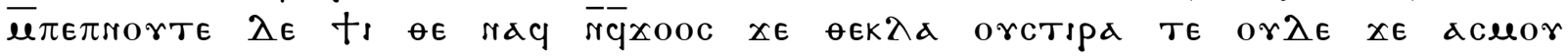

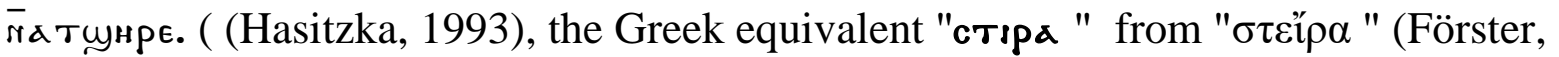

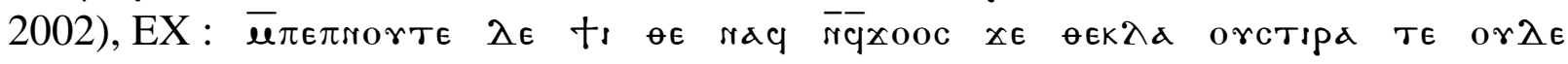

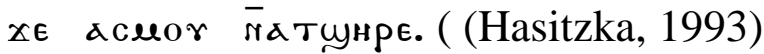

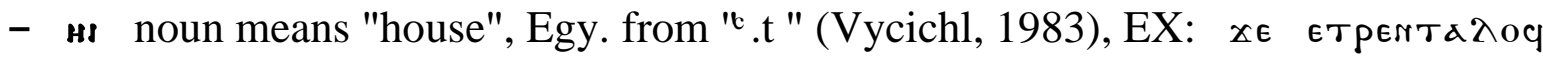

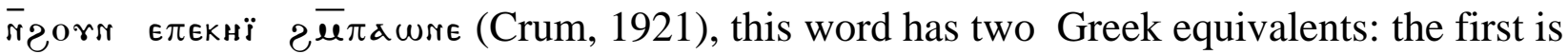

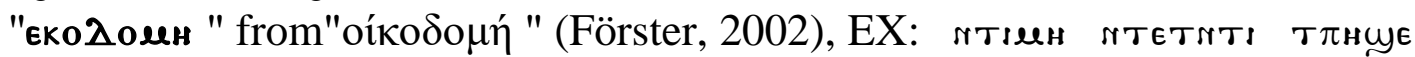
гтеколдощн (Crum, 1912), the second is "osкос " from "oíkos" (Förster, 2002), EX: eIte ïze eIte taktor eIte hr eIte orko. (Till, 1958) - kace noun means "shoemaker" (Crum, 1939), Egy. from"gs" (Vycichl, 1983), EX :

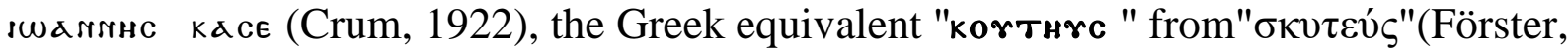

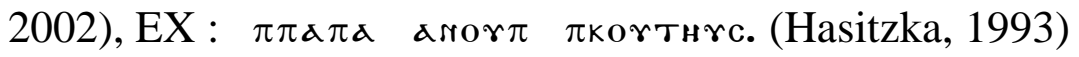

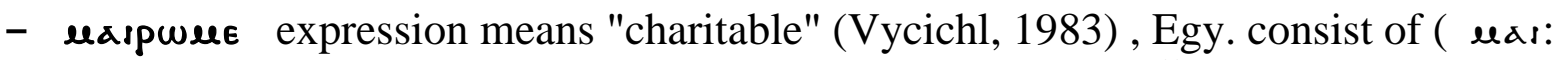
previously explained, pweє: noun means "father", from "rmt"(Černy, 1976) ), Ex :

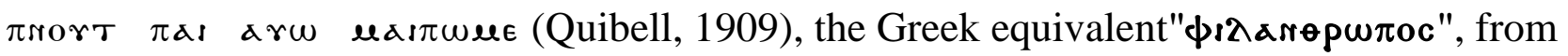

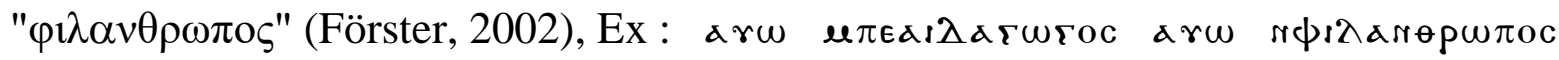
¿ $\lambda$ нөшc. (Ernštedt, 1959)

- елтлєтогаaß expression means "purity", Egy. consist of ( елт: prefix forming abstract nouns (Vycichl, 1983), from "mdt"(Černy, 1976), $\pi \in$ тoraa $B$ : adjective means

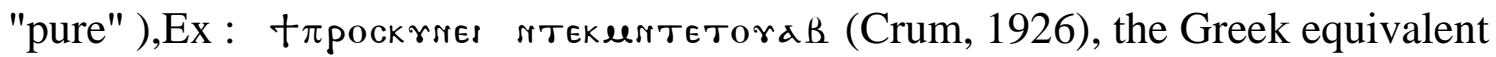

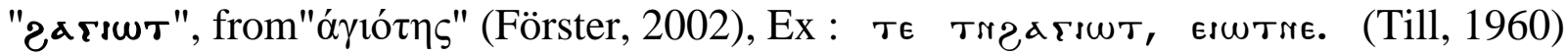
- exysp noun means "name of $6^{\text {th }}$ month", Egy. from"mhir" (Westendorf, 1977) EX :

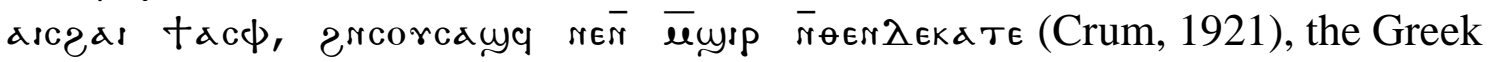

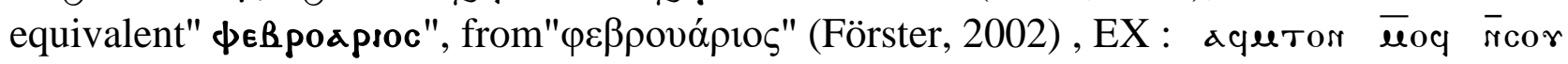
uñtтaqte $\pi$

To express the name of $6^{\text {th }}$ month, the Copts always used the word eusrp, while the Greek synonym $\phi \in$ Rpodproc was not known to the Copts, and its use in Coptic documents is an individual case, so the writer had to use the explanatory particle $\in \tau \in$ after it and used its Coptic equivalent to clarify the meaning, which proves that the Greek word is unfamiliar to them.

- пгот verb means "believe", Egy. from "nḥty" (Vycichl, 1983), Ex: рwщє єят̄ৃот

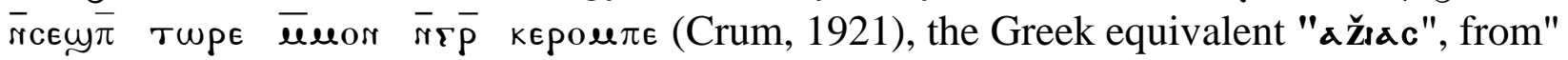




\section{JOURNAL OF THE FACULTY OF ARCHAEOLOGY -VOLUME 25 -2022}

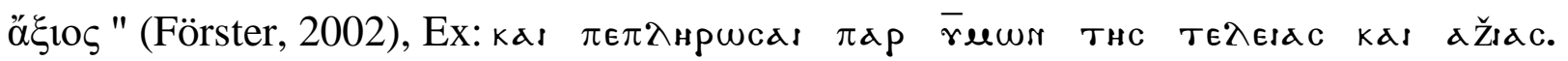
(Till, 1958)

- cштє verb means "release", Egy. from"st3" (Westendorf, 1977), EX: щлхwрнщх

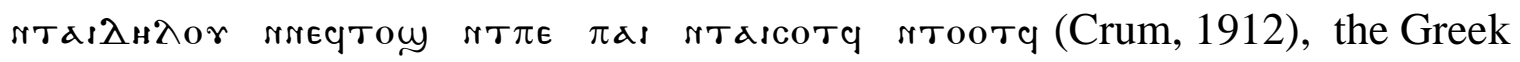

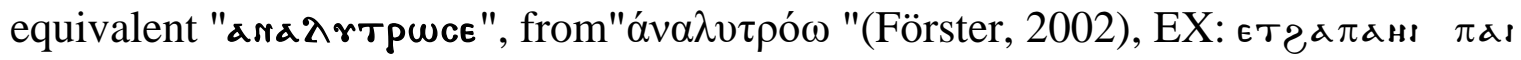

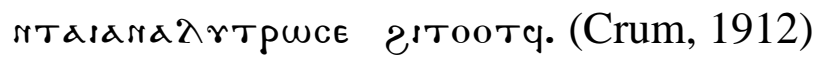

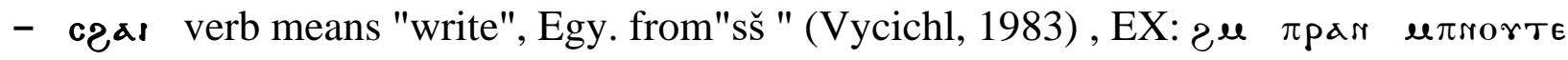

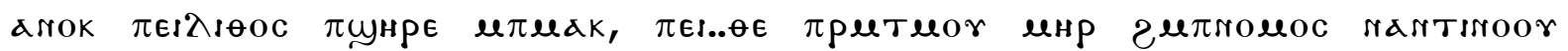

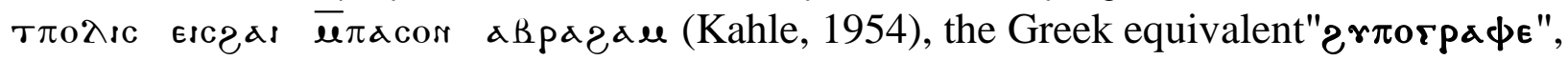

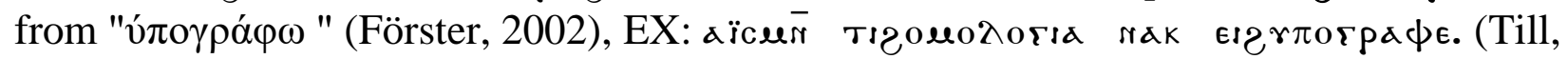
1960)

- релкнек expression means "Egyptian- man of Egypt" (Crum, 1939), Egy. consist of ( pщ: prefix means "man of ", from "rmt " (Černy, 1976), кнщє: noun means "Egypt", from

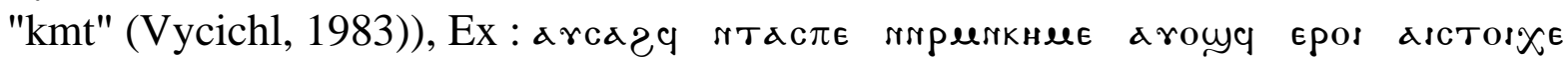
epoq(Crum, 1912), the Greek equivalent"аıг

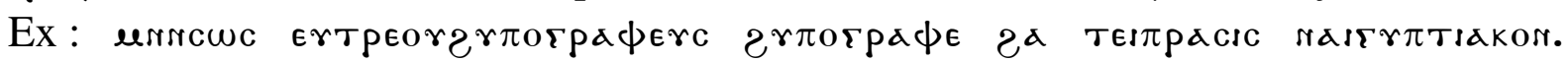
(Till, 1958)

- сулнре noun means "wonder", Egy. from"hpr "(Černy, 1976), EX : † латащештя

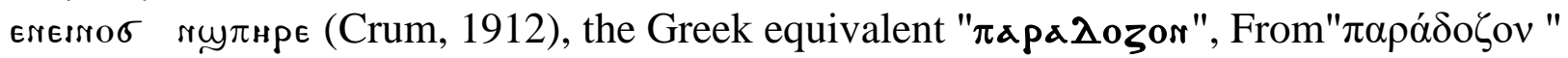

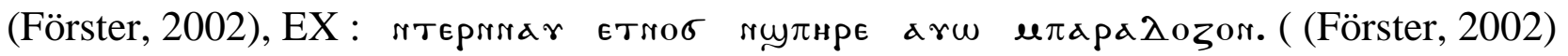

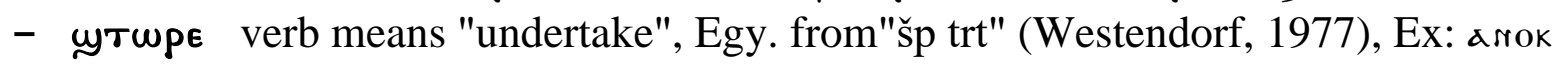

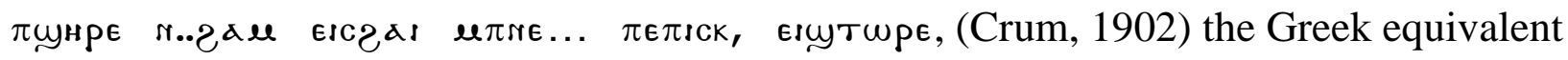

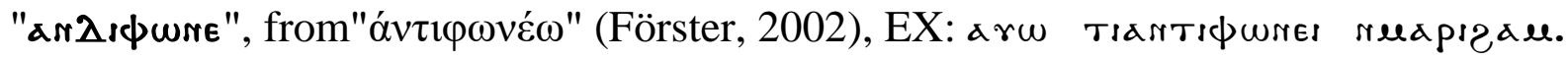
(Till, 1958)

- 2нRc noun means "lamp", Egy. from"hps " (Westendorf, 1977), EX : rce rorxor

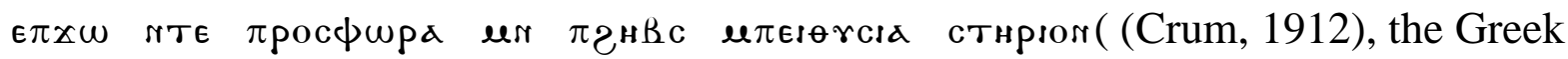

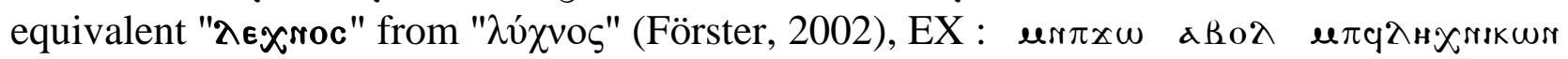

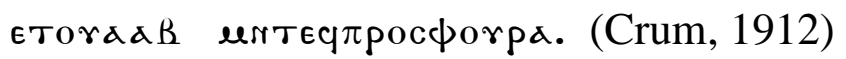

- orxar noun means "cure", Egy. from "wdi3" (Černy, 1976), Ex: $\lambda \epsilon$ eurscoc

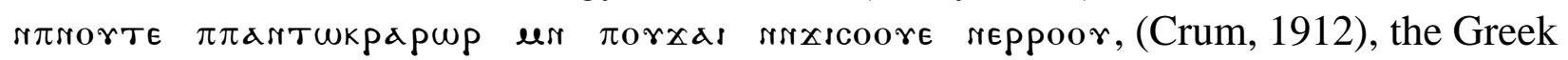

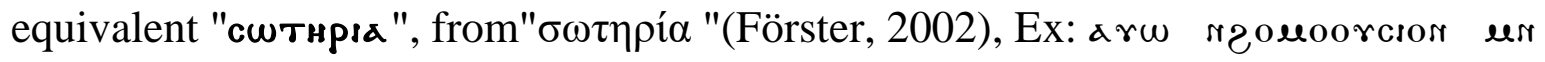
тсштнріа rserascoore. (Crum, 1912)

\section{Partial Synonyms}

A group of Coptic and Greek synonyms that can be called semi-synonyms, which generally have the same meaning, and their use was common in documents, but the study concluded that the Copts differed in the use of the Coptic synonym from their Greek equivalent, which can be inserted it in the writing methods used by the Copts. 


\section{The linguistic synonymy phenomenon of Coptic words and their Greek equivalent through the published Coptic documents}

- €вот noun means "month", Egy. from "3bd", (Westendorf, 1977), EX: єтє $\pi \AA \ddot{i} \pi \epsilon$

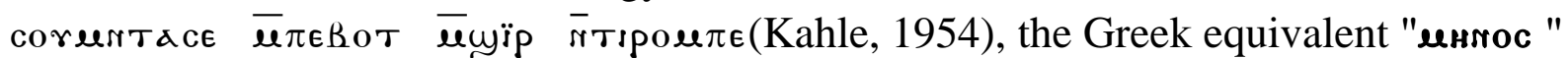

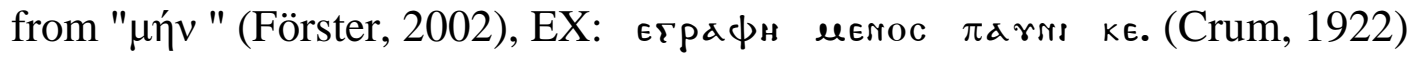

The word "єВот" is used either in the date formula which is often written in the middle of

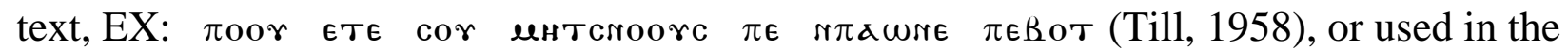
general context to express the word "month "without mentioning a date. This use is limited

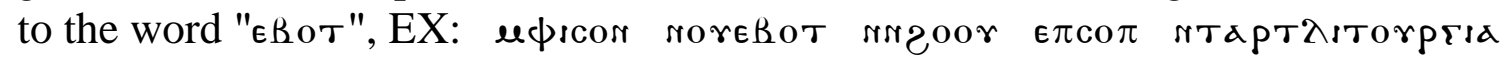
(Crum, 1902), while the word "uнsос "is mostly used in the date formula, Which is often written at the end of the text and that was often preceded by the word "єграфн".

- eıwт noun means "father " (Crum, 1939), Egy. from "it" (Černy, 1976), EX:

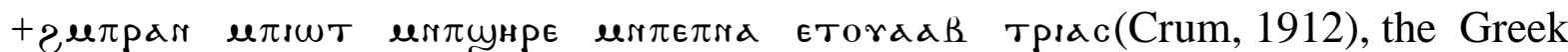

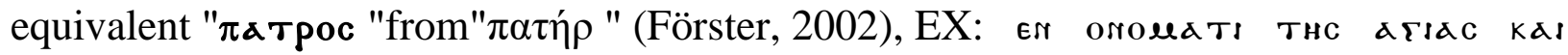

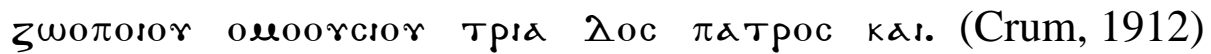

Both words were used in the meaning of the holy father as a god in the blessed formulas of the holy trinity however, the Coptic word esw $\pi_{\AA}$ Tpoc which was used only in this meaning in Greek formulas origin, whereas the word "єлшт" was used in same meaning but the blessed formulas of ancient Egyptian origin, and used also in another context which meaning father as a person.

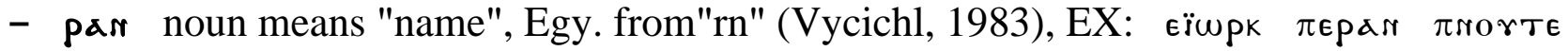

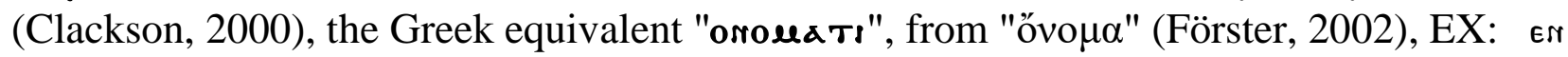

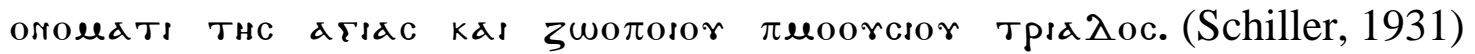

The Greek word was used only in the blessed formulas of the holy trinity of Greek formulas origin, Whereas the word par was used in either the blessed formulas of ancient Egyptian origin or in any other context that includes the meaning "name".

- co $\pi$ c verb means "entreat "Egy. from"spr" (Vycichl, 1983), Ex: arok kd EтcZd

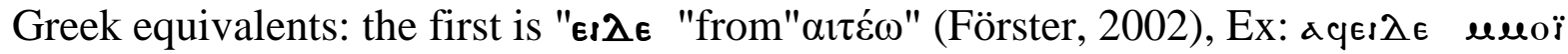

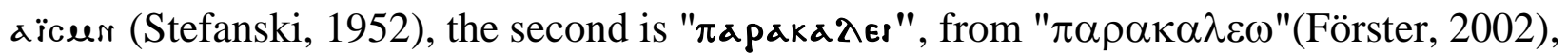

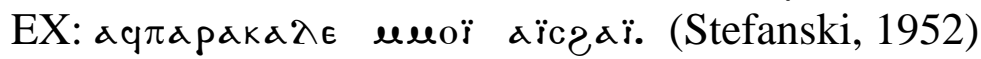

The two Greek verbs were often used together in the same documents EX: edses

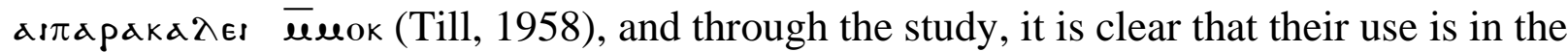
case of demand in general, while the Coptic verb co $\pi \mathrm{c}$ used mostly in the formulas of invoking the god or the saints in addition to the formula of the scribes and witnesses, and it is noted that it often preceded by one of the Greek synonyms нтеs or $\pi \Delta p \AA k \Delta \lambda \in s$ mostly to clarify and emphasize the intended meaning by using different words, EX: елнтел еIсолc

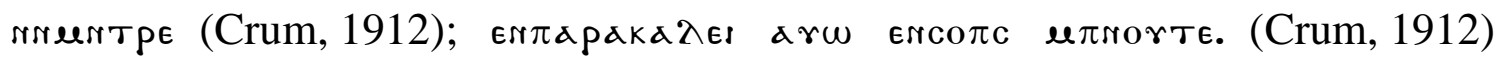

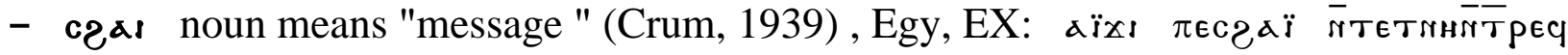

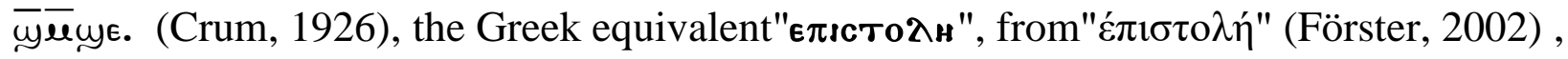

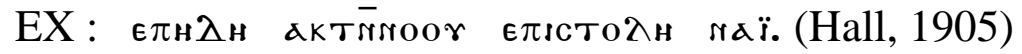


The Greek synonym $є$ лsсто $\lambda_{H}$ was the most used, and it seems that the Copts did not have any of the Coptic words to express the meaning of " message", so they borrowed this Greek word until they used the Coptic verb cəd $\ddot{i}$, which means "write" as a noun to express the meaning "message", by adding the definite article before it.

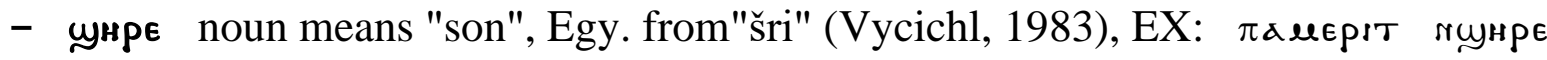
dedracro (Crum, 1912), this word has two Greek equivalents: the first is "esнor"from

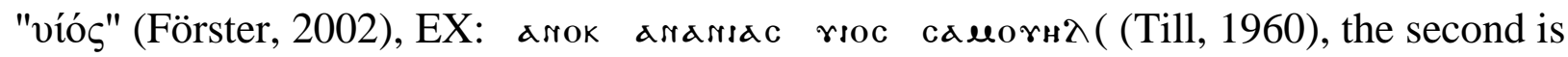

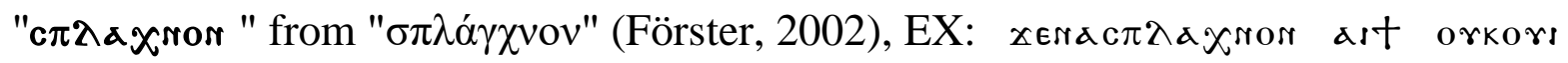
(Crum, 1912).

Both words уунрє and єлноr were used in the meanings of either the son as a person (as in the previous examples ) or the son of god in the blessed formulas of the holy trinity, EX :

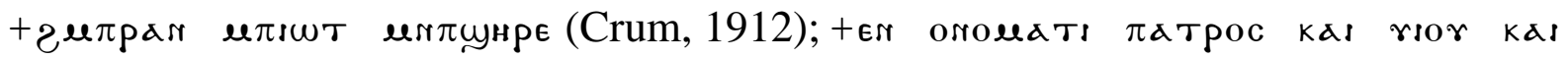
aรsor $\pi$ rereedtsc (Crum, 1912), as for the word c $\pi \lambda a$ xror was used only in the meaning son as a person, sometimes used in the same document with the word сунре may be to show the writer's knowledge of Greek language or to avoid repetition the word in the same document.

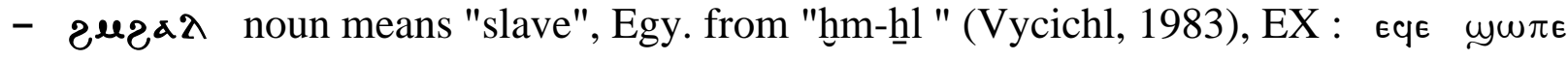

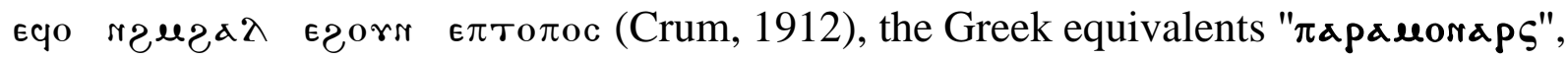

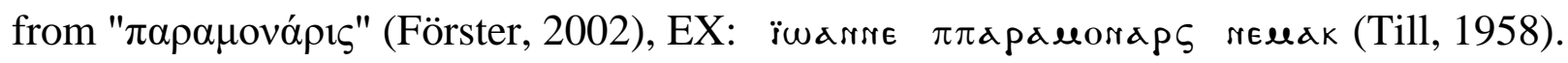
The Coptic word is used to express service in a holy place such as a monastery or church, while the Greek word is used to express the servant craft in daily life works.

\section{Conclusion:}

- The phenomenon of linguistic synonymy is one of the distinguishing characteristics of Coptic language that shows its richness and the ability of the Copts to expanding the methods of expressing the same meaning and how to differentiate in the use of some of these synonyms.

- The research reached the possibility of dating this phenomenon at the beginning of the seventh century $\mathrm{AD}$, but before that, the use of Greek vocabulary was limited to express only the meaning has no Coptic equivalent.

- The research found the semantic differences between some Coptic and Greek synonyms.

- The Comparative study of synonyms showed that there are complete synonyms that are completely identical and interchangeable with each other in any context, and other synonyms are partial synonyms which are words near in meaning, and differ in their inferential meaning were differentiated through the context.

- The use of this linguistic phenomenon in Coptic documents can be explained to several points:

- Numbers of these synonyms are used once in lists with their Coptic equivalent as a kind of learning the Greek language.

- There are Synonyms used together as one of the ways of emphasizing, where the word is emphasized with its synonym to strengthen the meaning and clarify it. 
The linguistic synonymy phenomenon of Coptic words and their Greek equivalent through the published Coptic documents

- Some Greek synonyms mostly came with the Coptic synonym in the same document to prevent the repetition of the Coptic synonym.

- Some Greek synonyms that were not familiar to the Copts were used in a few documents only to show the extent of the writer's culture and knowledge of the Greek language.

- Some Synonyms were used according to the writer's preferences, they were well known to the Copts, used as a kind of multiple expression of one meaning, which considered one of the writing methods for the Copts.

- Some synonyms follow written methods followed by the Copts, each of the Coptic and Greek synonyms had a different use. 


\section{References:}

- Biedenkopf - Ziehner, A. (2000), "Koptisch Ostraka II : Ostraka aus dem Ashmolean Museum", Wiesbaden, P.17.

- Černy, J. (1976), " Coptic Etymological Dictionary",Cambridge, PP.7,12,22,44,49,78,85,103,122,136-139,146,160,167,168,198,205,221233,250,264,280.

- Chassinat, É .( 1921),"Un Papyrus Médical Copte",Le Vésinet, N. XIV.

- Clackson, S. (2000), "Coptic and Greek Texts Relating to the Hermopolite Monastery of Apa Apollo", Oxford, Nos. 16,25,42.

- Crum, W.(1939), "A Coptic Dictionary", Oxford, PP. 9,18,86,121,156,216,256,295,297, 300,352,369,383, 439,581,619,671.

- Crum, W .(1905), "Catalogue of the Coptic Manuscripts in the British Museum", London, N. 491,1016, 1064, 1138.

- Crum, W (1909), "Catalogue of the Coptic Manuscripts in the collection of the John Rylands Library", Manchester, P. 282.

- Crum, W .(1893), "Coptic Manuscripts brought from the Fayyum", London, N. XXVII.

- Crum, W .(1902), "Coptic Ostraca from the Collections of The Egypt Exploration Fund The Cairo Museum And Others." London, P.59, Nos. 48,86,106,140,218,258,434,Ad.14.

- Crum, W .(1921), "Short texts from Coptic Ostraca and Papyri", Oxford, P. 193,198, Nos. 18,88,90,121, 186,300,354,387.

- Crum, W. (1926)," The Monastery of Epiphanies at Thebes II", New York, Nos. $85,146,170,181,210,307$.

- Crum, W. (1939)," Varia Coptica", Aberdeen, N.28.

- Crum, W.\& Bell, H (1910), Greek Papyri in the British Museum, IV, London, P. 1508.

- Crum, W.\& Bell, H. (1922)," Wadi Sarga Coptic and Greek Texts" Hauniae, Nos. 29,60,83,161,164,177.

- Crum,W. \& Steindorff, G. (1912), "Koptische Rechtsurkunden des 8.Jh. Aus Djeme (Theben), Leipzig", Nos.

1,9,16,18,20,24,35,36,44,47,50,52,58,65,67,75,79-89,91,95,100,106.

- Ernštedt, P. (1959)," Kopitskie teksty gosudarstvennogo Ermitaža ", MoskauLeningrad, 1959, P. 12.

- Förster, H .(2002), "Wörterbuch der Griechischen Wörter in den Koptischen Dokumentarischen Texten", Berlin.

- Hall, H .(1905), " Coptic and Greek Texts of The Christian Period from ostraca, Stelae, etc. in The British", oxford, Nos. XLI, XLIII.

- Hasitzka, M .(1987), " Koptische Texte",Wein, Nos. 11,12.

- Hasitzka, M .(1993), "Koptische Sammelbuch I", Wien, Nos. $036,242,471,479,719$. 


\section{The linguistic synonymy phenomenon of Coptic words and their Greek equivalent through the published Coptic documents}

- Kahle, P .(1954), "Coptic Texts from Deir el-Balaizah in Upper Egypt I-II", Berlin, Nos. 102,119,138.

- Leipoldt, J. \& Erman, A. (1904), " Ägyptische Urkunden aus den Königlichen Museen zu Berlin 1", Berlin, N. 78.

- Quibell, J .(1909), " Excavations at Saqqara (1907-1908)", Ie Caire, N. 135.

- Rémondon, R. (1965)," Le Monastère de Phoebammon dans la Thèbaïde", Le Caire, P. 19b,

- N. 21.

- Satzinger, H. (1968)," Ägyptische Urkunden aus dem Staatlichen Museum Berlin.Koptische Urkunden, III", Berlin, P. 336,355.

- Schiller, A. (1931)," Ten Coptic Legal Documents", New York, N. 1,4.

- Stefanski, E .\& Lichthiem .M .(1952), " Coptic Ostraca from Medinet Habu",Chicago, Nos. 37,57-59,72,90.

- Till, W .(1951), " Die Arzneikunde der Kopten", Berlin, N. 80.

- Till, W. (1956)," Die Koptischen Arbeitsvertäge", Warschau-Breslau, Nos. 13,14 .

- Till, W. (1960)," Die Koptischen Ostraka der Papyrussammlung der Österreichischen Nationalbibliothek. Texte, Übersetzungen, Indices", Wien, Nos. 27,99,113,412.

- Till, W. (1958)," Die Koptischen Rechtsurkunden der Papyrussammlung", Wien, Nos. 10,17,27, 32, 34, 35, 71,102,117,123,147,158,160,177,250.

- Vycichl, W. (1983)," Dictionnaire étymologique de la Langue Coptie", Leuven, PP. 14,17,28,33, 44,52,54,64,81,107,117,125,139,145,152,172$176,181,194,204,223,231,269,278,296,306$.

- Walaa, A. (2021), " The wine in Everyday life through Coptic sources", in: General Union of Arab Archaeologists, 22, Vol. 2, Doi: 10.21608/jguaa.2021.59952.1158, P. 346. (in Arabic)

- Westendorf, W .(1977), " Koptisches Handwörterbuch", Heidelberg, PP. $16,33,47,53,109,111,134,145,200,218,261,293,325,332,355,381$. 